\title{
Blueprint for breakdown? Community Based Management of rural groundwater in Uganda
}

Marije van den Broek*
Marije.vandenbroek@ port.ac.uk

Dr. Julia Brown

Julia.brown@port.ac.uk

University of Portsmouth, Department of Geography, Buckingham Building, Lion Terrace, Portsmouth PO1 3HE, United Kingdom

*Corresponding author

\begin{abstract}
The belief that groundwater in rural areas is best managed according to the Community Based Management (CBM) model is the dominant paradigm across SubSaharan Africa. While donors and governments focus on extending the supply network to meet the post-2015 Sustainable Development Goal (SDG) of universal access to clean water, at any one time a third of handpumps are non-functional. Basing our case on ethnographic fieldwork, surveys and interviews, and working closely with policy implementers over the course of three years in mid-west Uganda, we argue that non-functionality of handpumps, and the precarious status of many, cannot be blamed solely on poor technology or siting of wells: rather the problem stems from a dearth of maintenance funds and management failings. The CBM model is an uneasy coalition of ideologies from across the political spectrum that meshes neo-liberal inspired commodification with theories of collective action and Common Property Resources. We demonstrate conceptually and empirically how the wings of the CBM model individually and collectively are contributing to the disappointing outcomes amid the messy complex reality of rural environments. Recommendations calling for modifying participatory processes, technological solutions and more external support all fall within the existing CBM framework, which we will empirically demonstrate is a blueprint for breakdown in these contexts. A resolution to the financing of handpump maintenance must be found if the SDG is to be realised, and we argue that academics, policy makers and practitioners need to accept this may lie outside the CBM paradigm.
\end{abstract}

Key words: rural groundwater, handpumps, Sub-Saharan Africa, Community Based Management, commodification, Common Property Resources 


\section{Introduction}

The objective of this article is to examine the underlying ideologies and theoretical underpinnings of the Community Based Management (CBM) model - the dominant paradigm in rural water management in sub-Saharan Africa - and the resultant disappointing outcomes across two decades.

By the 1990s, it was broadly acknowledged recognised that the top-down state-led paradigm for water provision had largely ignored and ultimately failed rural communities across Sub-Saharan Africa (SSA) (Fritz and Menocal, 2006; Harvey and Reed, 2006; Le Gouais and Wach, 2013; Moriarty et al., 2013; Miller, 1980; ParryJones et al., 2001). Where provision was made by the state, the expectation of beneficiaries was that access should be free and maintenance not their responsibility-a mindset that largely persists into the present time (Jones, 2011; Quin et al.,2011; Whittington et al., 2009, Fritz and Menocal, 2006; Woolcock and Prichett, 2004). To combat the acknowledged poor provision in rural areas, ${ }^{1}$ and as a route to more sustainable access to water in developing countries, the CBM model was promoted and promulgated in rural areas, whereby communities demand a water service, decide the technology, contribute towards the construction, voluntarily manage the water source and pay for its upkeep (Briscoe and Ferranti, 1988). We argue that the CBM model is a paradoxical ideological amalgam of grassroots post-Marxist developmentalists: the 'new' Left on the one hand, and on the other, neo-liberals, the 'new' Right. Both promote the rolling back of the state, more local control and selfreliance (Mohan and Stokke, 2000). Both advocate collective action, the former in the absence of trust in African politicians and government agencies (Page, 2003) and the private sector (Shiva, 2002), the latter in order to cut state deficits by promoting the commodification of water, thereby ensuring the community covers Operation and Maintenance (O\&M) costs (Blaikie, 2006). The CBM model is a paradigm of its era (1990s) when there was faith in so-called Third Way politics and policy programmes that promised win-win outcomes (Mohan, 2002). Because support comes from both ends of the political spectrum, the CBM model has proved very dominant and to date the prevailing view of donor agencies, policy makers and academics in the rural water circle is "that communities can and should take full responsibility for their [water] systems" (Whittington et al., 2009 p. 714).

At any one time, however, one out of three handpumps is non-functional across SSA (Baumann 2006; Oxford/RFL, 2014; RWSN, 2010). Statistics for non-functionality of handpumps are no better than they were in the state-led era (Evans, 1992) maintenance has been, and continues to be, the stumbling block. The magnitude of the challenge is evident when in five years' time it is estimated that $57 \%$ of the global population will be dependent on communally-managed water points (Joint Monitoring

\footnotetext{
${ }^{1} 22 \%$ of rural populations had access to an improved water source in 1980 compared with $66 \%$ of their urban counterparts (WHO, 1992).
} 
Program, 2011), further exacerbated by growing populations and the often detrimental impact of climate change (Oates et al., 2014; Schlosser et al., 2014).

We investigate how the CBM model is interpreted and implemented in Uganda. Through original and rigorous ethnographic fieldwork, surveys and interviews (across a total of 107 unique water points - 95 were constructed by a local NGO with whom we had strong links, the remaining twelve were constructed by the local government) we analyse the outcomes of community-managed rural groundwater points in midwest Uganda.

Our findings lend support to a body of empirical study that is beginning to show that the problem of handpump non-functionality is fundamentally related to the CBM model (Barnes et al., 2014; Baumann and Furey, 2013; Jiménez and Pérez-Foguet, 2010; Jones, 2011), more specifically the dearth of collected funds for O\&M (Burr and Fonseca, 2013; Jones, 2011). There is a reluctance amongst academics and practitioners to challenge the CBM model (see Blaikie, 2006 p.1944) - rather, deliverance is sought within the existing paradigm in calls for tweaking the participatory processes, offering technological solutions and more external support. This is where our study diverges - we demonstrate that there is a fundamental mismatch within the framework that attempts to mesh the commodification of water with collective action amid the messy complex reality of rural environments. We then offer insights into why recommendations for improvements that fall within the CBM paradigm will struggle to succeed. In so doing we make a contribution to academic and practitioner debates and the growing geography of water literature.

The paper proceeds with a review of the literature on the CBM model and its conceptual underpinnings, followed by a summary of the recommendations offered in the literature to shore up the model. This is followed by our case study on the implementation of rural water projects and the status of community-managed rural water points in Masindi and Kiryandongo districts in Uganda, with a discussion and conclusion to close.

\section{The Community Based Management model for rural water management}

The CBM model comprises two phases, the first of which is referred to as the Demand Responsive Approach (DRA) (Sarah and Katz, 1998). This encourages communities to demand a service, decide the technology, contribute towards the construction and form a local institution - a Water User Committee (WUC) - to manage the water source (Breslin, 2003). The second and ongoing phase is postconstruction where the elected WUC voluntarily oversees O\&M of the water source and collects the fees from users (Lockwood, 2004). It is through these two stages that sustainability is envisaged, embracing participation from the outset with the resultant empowerment and sense of ownership combining to ensure the community is willing to pay and volunteer their time to keep the system running (Doe and Khan, 2004). 
The CBM model is an uneasy coalition of ideologies that mesh theories from opposite ends of the political spectrum. We argue that each wing of the model rests on some rather tenuous assumptions about human behaviour. The grassroots arm of the CBM model draws upon theories of collective action and Common Property Resources (CPR), and is committed to positive notions of community, participation, social capital and self-regulating local water institutions.

A practitioner handbook on "managing natural resources for development in Africa" describes a community as: "[a] group of people bounded by geographical links, such as a village, settlement or district, politics or natural boundaries but also includes those brought together by lifestyle, culture, religion, hobby and interest" (Wasonga et al., 2010 p. 167). However, such conceptualisations of African community are problematic (Cleaver, 1999; 2001). The World Bank (2010) notes that substantial changes are taking place in rural areas due to increased employment, communications, wealth and individualism. Neither are communities necessarily homogenous as Harvey and Reed (2006) and Lockwood (2004) point out: no two rural communities are the same and differences also exist within communities caused by wealth, gender, ethnicity or religion. Finally, communities are often far from harmonious, and the concept "conceals power relations" and "masks biases in interests and needs" (Guijt and Shah, 1998 cited in Cooke and Kothari, 2001 p.6). Cleaver (1999) takes it a step further and declares 'community' a "myth" (p. 603).

If communities do not live up to their populist cohesive image, then their willingness to participate cannot be taken for granted. The decision to participate or not may be a rational or an unconscious choice, embedded in social norms (Cleaver, 2001), and is dependent on age, gender and class (Holmes and Scoones, 2000). Participation often benefits elites (Brown, 2013; van Koppen et al., 2012), thus challenging the belief that it is an indisputable good (Cooke and Kothari, 2001). Further, it is probably unrealistic to expect a representation of all water users in the design, implementation and post-construction phases of water schemes. Nevertheless, it appears that water practitioners have embraced the "cultural idealisation of rural communities" (Harvey and Reed, 2006 cited in Moriarty et al., 2013 p. 331).

Participation during the implementation stages of a rural water project is perceived to increase the stock of social capital amongst water users (Narayan, 1995). This is invariably viewed as a positive community characteristic ${ }^{2}$, which will enhance a community's ability to act collectively and ultimately manage a water source sustainably (Bisung and Elliott, 2014; Bisung et al., 2014; Krishna and Uphoff, 2002).

\footnotetext{
2 Features such as interpersonal trust, norms of reciprocity and mutual aid that bind a group together are a gauge of the stock of social capital (Coleman, 1988; Putnam 1993, 2000).
} 
The establishment of self-regulating institutions is central to the CBM model (Mosse, 2006), and is strongly influenced by Common Property Resource theory and the work of Elinor Ostrom and her eight design principles (Table 1) (1990, 1998, 2000). Individuals participate in collective action and develop institutions to govern their behaviour in order to benefit from "productive outcomes in situations where temptations to free-ride and shirk are ever present" (Ostrom, 1990 p.29). Similarly, North (1990) claims institutions reduce uncertainty and propel collective action. For development practitioners, the formation of local institutions is attractive as they represent a tangible embodiment of an idealised notion of 'community' (Mosse, 2006), undertaking visible collective action, where rules are developed and executed (Ostrom, 1990) and are easy to influence, amend and analyse (Scott 1998, in Cooke and Kothari, 2001). Cleaver (1999), however, asserts that actual water management is "embedded in social networks, daily interactions and the application of social norms" that may lie outside formal institutional arrangements (p. 602).

Table 1

Ostrom's design principles (1990, p. 90).

1. Clearly defined boundaries

Individuals or households who have rights to withdraw resource units from the CPR must be clearly defined, as must the boundary of the CPR itself.

2. Congruence between appropriation and provision rules and local conditions Appropriation rules restricting time, place, technology, and/or quantity of resource units are related to local conditions and to provision rules requiring labour, material, and/or money.

3. Collective-choice arrangements

Most individuals affected by the operational rules can participate in modifying the operational rules.

4. Monitoring

Monitors, who actively, audit CPR conditions and appropriator behaviour, are accountable to the appropriators or are the appropriators.

5. Graduate sanctions

Appropriators who violate operational rules are likely to be assessed graduated sanctions (depending on the seriousness and context of the offense) by other appropriators, by officials accountable to these appropriators, or by both.

6. Conflict-resolution mechanisms

Appropriators and their officials have rapid access to low-cost local arenas to resolve conflicts among appropriators or between appropriators and officials.

7. Minimal recognition of rights to organise

The rights of appropriators to devise their own institutions are not challenged by external governmental authorities.

For CPRs that are parts of larger systems:

8. Nested enterprises

Appropriation, provision, monitoring, enforcement, conflict resolution, and governance activities, are organised in multiple layers of nested enterprises.

Ultimately, how effectively communities undertake collective action depends on formal and informal relationships that: (1) restrain water users from free-riding, (2) motivate people to participate in the management of the water source, and (3) aid water users to craft and enforce rules that govern the water system in the village (Kähkönen, 1999). The challenge in Uganda lies in whether Ostrom's (1990) success stories of long-standing communally managed fisheries, forest and canal irrigation 
schemes can be duplicated for communally managed water points. There is no certainty that these isolated small-scale examples of organic collective action can be scaled-up through the imposition to comply with government policy (Mansuri and Rao, 2013 p.33).

The other arm of the CBM model, influenced by neo-liberal agendas, is the acceptance that water should be treated as a commodity and paid for. Instrumental were the 1992 Dublin Principles where governments and the international donor community declared water as an economic good and agreed that water should be managed at the lowest possible level (Sara and Katz, 1998). To begin with, we must clarify what 'goods' and 'services' are being commodified under the CBM model. While groundwater (the 'goods') is untreated, capital and labour investments must be supplied and financed in order to initially access the resource through the construction of boreholes and Shallow Hand Dug Wells (SHDWs), and in order to sustain access, handpumps must be maintained which incurs labour and material costs which are priced through the market. In the $\mathrm{CBM}$ model, users are required to contribute towards the construction of the water source (usually between 5 and 10\%); the balance is financed by either NGOs or local government. So, in reality construction costs are heavily subsidised. The important underlying assumptions are that monetary contributions are affordable, are willingly paid and ultimately engender feelings of ownership, which once the scheme is turned over to the community to manage will translate into their on-going willingness to pay the full maintenance costs ${ }^{3}$ that are crucial for the long-term functionality of the handpumps (Burr and Fonseca, 2013; Jones, 2011; Schouten, 2006). A central tenet of the CBM model is that management 'service' provided by the community following turn over of the scheme is voluntary - in other words this 'service', unlike the physical water, has not been commodified and remains outside the market.

When considering both ideological arms of the CBM model it is assumed that collectively they are complementary i.e. that commodification does not distort collective action and CPR theory. Paying for the O\&M of the water point in the CBM model sets water apart from other CPR resources where financial contributions are rarely mandatory. Further, as a resource, drinking water is a special case because of the Human Right to water - which compromises Ostrom's design principle to combat free riding through the imposition of graduated sanctions such as denial of access to the resource for infringements and habitual non-payment. Drinking water has earned itself the label of an 'uncooperative commodity' (Bakker, 2003) because of the difficulty of reconciling the need to treat it as an economic good with its status as a basic Human Right whereby the CPR penalty of exclusion for non-payment is socially and ethically impossible to enforce.

\footnotetext{
${ }^{3}$ Communities are not paying for water per unit consumed, as is common in urban areas (Bakker, 2003).
} 


\subsection{Recommendations from the literature to improve the outcomes of community managed water points}

Evidence is growing that the high failure rates of communally-managed sources and the lack of O\&M is due to the dearth of funds to pay for O\&M (Jones, 2011; 2013; Le Gouais and Wach, 2013; Nabunnya et al., 2012), in conjunction with the waning of community interest and a reluctance to volunteer on the WUC (Harvey, 2007; Lockwood and Smits, 2011; Quin et al., 2011). View Table 2.

Table 2

Reasons for lack of Operation \& Maintenance funds

\begin{tabular}{|c|c|}
\hline Political factors & $\begin{array}{l}\text { - Interference of local politicians that advertise for free water in return for votes } \\
\text { (Carter et al., 2010; Quin et al.., 2011). } \\
\text { - Lack of legal status and authority of WUC (Harvey, 2007; Lockwood and } \\
\text { Smits, 2011). }\end{array}$ \\
\hline
\end{tabular}

Historical

factors

Geographical factors

Social factors

Implementation factors

- The general belief among people that water should be free of charge as practised during the state-led paradigm, and expectation of external financial support by government and NGOs (Jones 2011; Quin et al., 2011; Whittington et al., 2009).

- Alternative water sources reduce people's willingness to pay for water from protected sources (Parry-Jones et al., 2001).

- Water users mistrust the WUC due to the fear of mismanagement of funds (Harvey et al., 2006; Jimenez and Perez-Foguet, 2010; Kamruzzaman et al., 2013; Kleemeier and Narkevic, 2010; Montgomery et al., 2009).

- Preference of community members is to only pay user fees when the pumps breakdown. This actually makes the life of WUC simpler, and community members rather spend available money on other projects (Whittington et al., 2009).

- WUC not able to efficiently collect water user fees from community members (Whittington et al., 2009; Quin et al., 2011).

- Trained WUC members are not willing to work on a voluntary basis, lack access to skills upgrading, forget their initial training, or simply move away (Harvey, 2007; Lockwood and Smits, 2011; Quin et al., 2011).

- The enforcement of graduated sanctions for non-payment causes internal conflict (Golooba-Mutebi, 2012).

- Satisfaction and demand of the service (Barnes et al., 2014; Bhandari and Grant, 2007; Harvey, 2008; Jimenez and Perez-Foguet, 2010).

- Community receives insufficient education about the costs of O\&M of the water source (Harvey 2008).

- Promises by implementing organisations that water is free of charge (Carter et al., 2010).

When project failure occurs, water practitioners predominantly look to three areas within the CBM model to improve O\&M of rural water points. First, unsuccessful water projects are attributed to the lack of community capacity and involvement. The solution is sought in improving the design and implementation of participatory processes (see Marks \& Davis 2012, p. 1575) and through activities aimed at enhancing the stock of social capital to increase the sense of obligation to volunteer 
involvement and deter free-riding (Kähkönen, 1999). Practical capacity building activities on maintenance, record-keeping and financial management are also recommended. Mandara et al (2013) advocate widening involvement to draw in public and private sector professions to train the WUCs and local technicians.

Second, technological solutions are promoted to provide early information about the functionality status of handpumps (see Thomson et al., 2012; Hutchings et al., 2012; Hope et al., 2011). Recent initiatives such as 'mobile/water for development' by Oxford University, 'SweetSense' by Portland State University and 'MoMo' by the NGO Welldone, use the mobile phone network for remote monitoring. According to Thomson et al (2012) “... analysis of recent historical usage data may provide some indication of the nature of the failure and thus speed up the repair cycle" (p.837).

A third set of recommendations to improve the sustainability of handpumps often involves the call for external support. Increasingly, both academics and practitioners appeal for post-construction support to communities to provide technical expertise and advice, administrative and financial support, auditing of accounts, and water quality monitoring (Barnes et al., 2014; Baumann and Furey, 2013; Carter et al., 2010; Carter et al., 1999; Harvey and Reed, 2006; Kamruzzaman et al., 2013; Kleemeier, 2010; Lockwood, 2004; Moriarty et al., 2013; Schouten and Moriarty, 2003). It is noticeable in the literature that there has been a slow retreat from faith in full citizen control over the water service: in the 1990s, the absence of postconstruction support meant a sustainable rural water facility because the WUCs were functioning and self-regulating (Parry-Jones et al., 2001; Visscher, 1997; Water and Sanitation Programme, 2000; Webster et al., 1999). Nowadays post-construction support is increasingly brought forward as a pre-condition for sustainability. The most logical provider of such support is local government (Koestler et al., 2010).

Despite increasing criticism about the functioning of the CBM model (Blaikie, 2006; Brown, 2013; Carter and Kidega, 2013; Cleaver 1999, 2001; Golooba-Mutebi, 2005; Harvey et al., 2006; Harvey and Reed, 2006; Jones, 2011; Koestler et al., 2010; World Bank, 2010) the majority of the reviewed literature is optimistic about finding solutions within the CBM model, rather than looking outside the paradigm.

\section{Uganda rural water context}

Uganda, in central East Africa, has an estimated population of 34.8 million (2014), of which $85 \%$ reside in rural areas (Uganda Bureau of Statistics, 2014). It is expected to experience water stress ${ }^{4}$ by 2025 , due to the rapid population growth (3.24\% in 2014), (CIA World Fact Book) and the ongoing degradation of the country's wetlands that regulate the groundwater system (Wong et al., 2005).

\footnotetext{
${ }^{4}$ When demand exceeds available supply or access is restricted due to poor quality. European Environment Agency www.eea.europa.eu
} 
The legal framework comprises, first, the Local Government Act (1997), revised 2000, which devolves responsibility for water provision, maintenance and follow-up support to local governments; second, the National Water Policy (1999) which stipulates that communities need to manage rural water points via a WUC, in accordance with the CBM model (view Figure 1) (Ministry of Water and Environment Uganda, 2007). The constitution of Uganda (1995), revised 2005, acknowledges access to clean water as a right to all Ugandans. Government policy was that $77 \%$ of the rural population would have access to an improved water point ${ }^{5}$ by 2015 , with $90 \%$ functionality of handpumps.

The Uganda Ministry of Water and Environment (MWE) in 2014 reported 64\% coverage and $85 \%$ functionality. However, it is argued official figures over-report functionality (Burr and Fonseca, 2013) as illustrated by the example of Kanungu district; officially $78 \%$ were functional, whereas the study of Koestler et al (2010) report $40 \%$.

\section{Study site, methods \& data collection}

Our study focuses on rural water points in six sub-counties across Masindi and Kiryandongo districts in mid-west Uganda (refer to Figure 2). Both districts are endowed with surface water and numerous wetlands. Smallholder agriculture is the main economic activity in the area (Kavuta and Edriss, 2015).

The objective of the research was to investigate the status of community-managed water points with reference to maintenance and financial viability, the functioning of WUCs and the effectiveness of collective action, in order ultimately to evaluate the CBM model. To this end questionnaire surveys and interviews were conducted between August 2013 and mid-November 2014. This was augmented by ethnographic fieldwork by the lead author who resided in Masindi from June 2012 to January 2014 as the programme manager of a local water, sanitation and hygiene NGO specialising in the construction of SHDWs. ${ }^{6}$ It is through this organisation that we gained access to the 95 sources that form the focus of our study. We were also able to collect data on twelve local government constructed sources through our links to local government officials.

Two discrete surveys concerning the NGO constructed water points were undertaken by NGO staff under the direction of the lead author. The first, with WUC members only and representing 84 sources, ascertained information and evidence of O\&M fund

\footnotetext{
${ }^{5}$ Defined as being within $1.5 \mathrm{~km}$ and providing a minimum per capita consumption of 20 litres per day. 6 The covered SHDWs have a depth of five - twelve metres and are fitted with British Consallen handpumps, with spare parts on sale at the local NGO office.
} 
Figure 1

Roles of key actors in the CBM model of rural water facilities (adapted from MWE, 2011 p. 11)

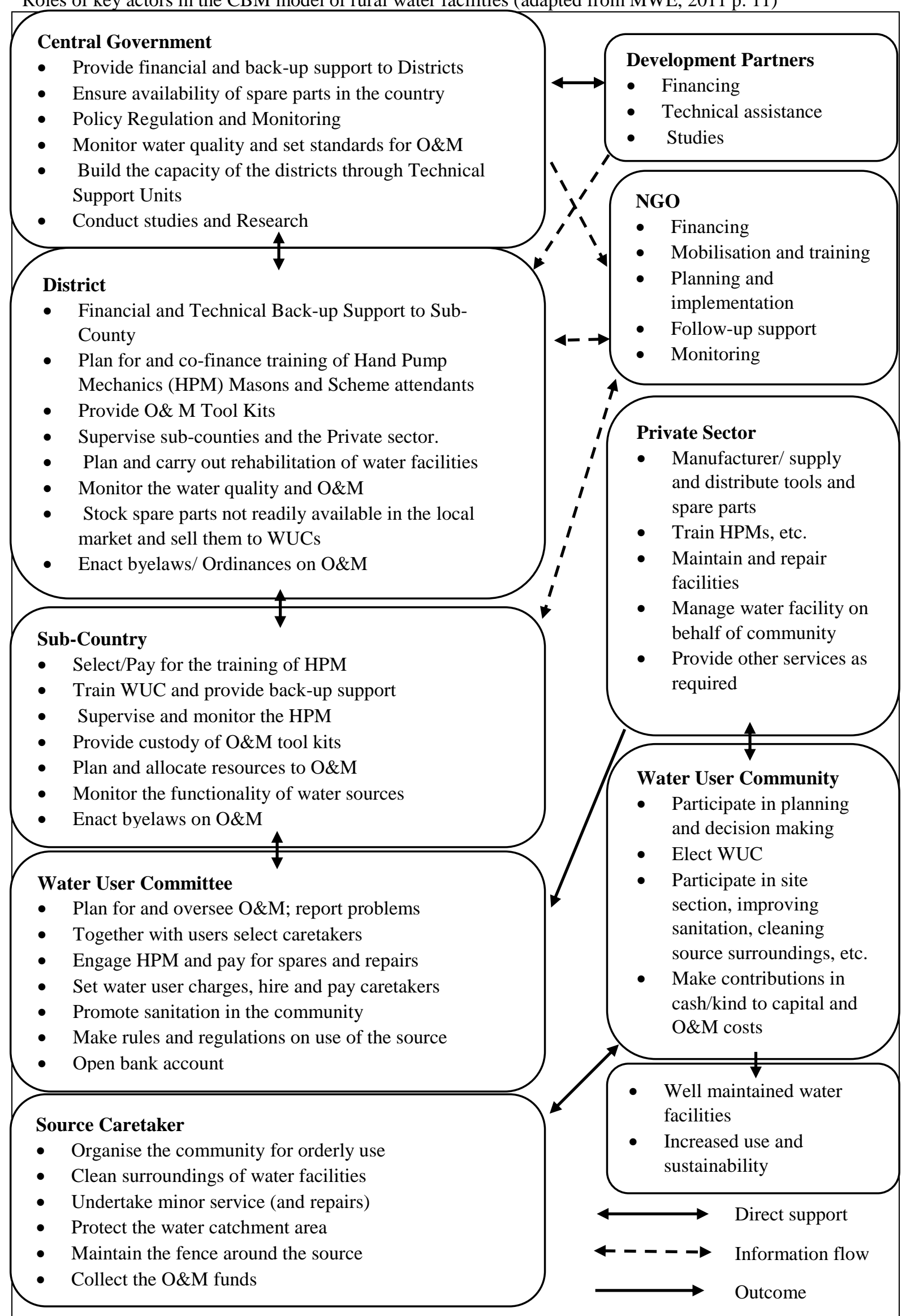


collection and WUC activities. The second survey concerned water users at thirteen sources. In total 195 respondents were randomly selected and surveyed about sources of water, their payment patterns for water use, and attitudes.

95 in depth semi-structured interviews were undertaken with WUC members and community users from 30 water sources in seventeen villages (of which twelve concerned local Masindi government constructed sources). Interviewees were asked to reflect on community relations, household composition and levels of education, involvement with the construction phase, satisfaction with the water point; roles and responsibilities of the WUC; the payment process of water user fees and O\&M collection; implementation of graduated sanctions and suggestions for improvement of O\&M.

As a result of overlap between the surveys and in-depth interviews, a total of 107 distinct sources were studied, representing a comprehensive data set.

Semi-structured interviews were conducted with eight staff members of the NGO, as well as five technical government officials from both sub-county and district level: (1) District Water Officer Kiryandongo; (2) Assistant Engineer Kiryandongo; (3) Assistant Engineer Masindi; (4) Sub-county chief Kigumba; and (5) Community Development Officer Kigumba sub-county. NGO and local government officials were asked about the implementation process of a rural water point and to reflect on their experiences of post-construction follow-up support and the O\&M of rural water points.

To calculate the financial sustainability of the studied water points we used the WASHCost benchmarks (Burr and Fonseca, 2013). View Table 3 for the estimated annual costs of minor and major repairs per technology.

\section{Findings}

The implementation stages of our NGO and local government constructed rural water points, from inception through to established operation, are presented in this section, with particular interest in the post-construction phase.

\subsection{Accessing Clean water}

In line with the Demand Responsive Approach and Uganda's rural water policy, each village has to demand a SHDW by writing an application letter, signed by the Local Councillor (LC) I (the lowest of the five levels of elected local government officials) to the provider (NGO or local government). Depending on size, each village can receive multiple protected water sources. In reality the initiative usually comes from the NGO, which makes the approach to villages deemed to lack clean water. This is because NGOs are under pressure from donors to meet targets. 
Figure 2

Map of study area

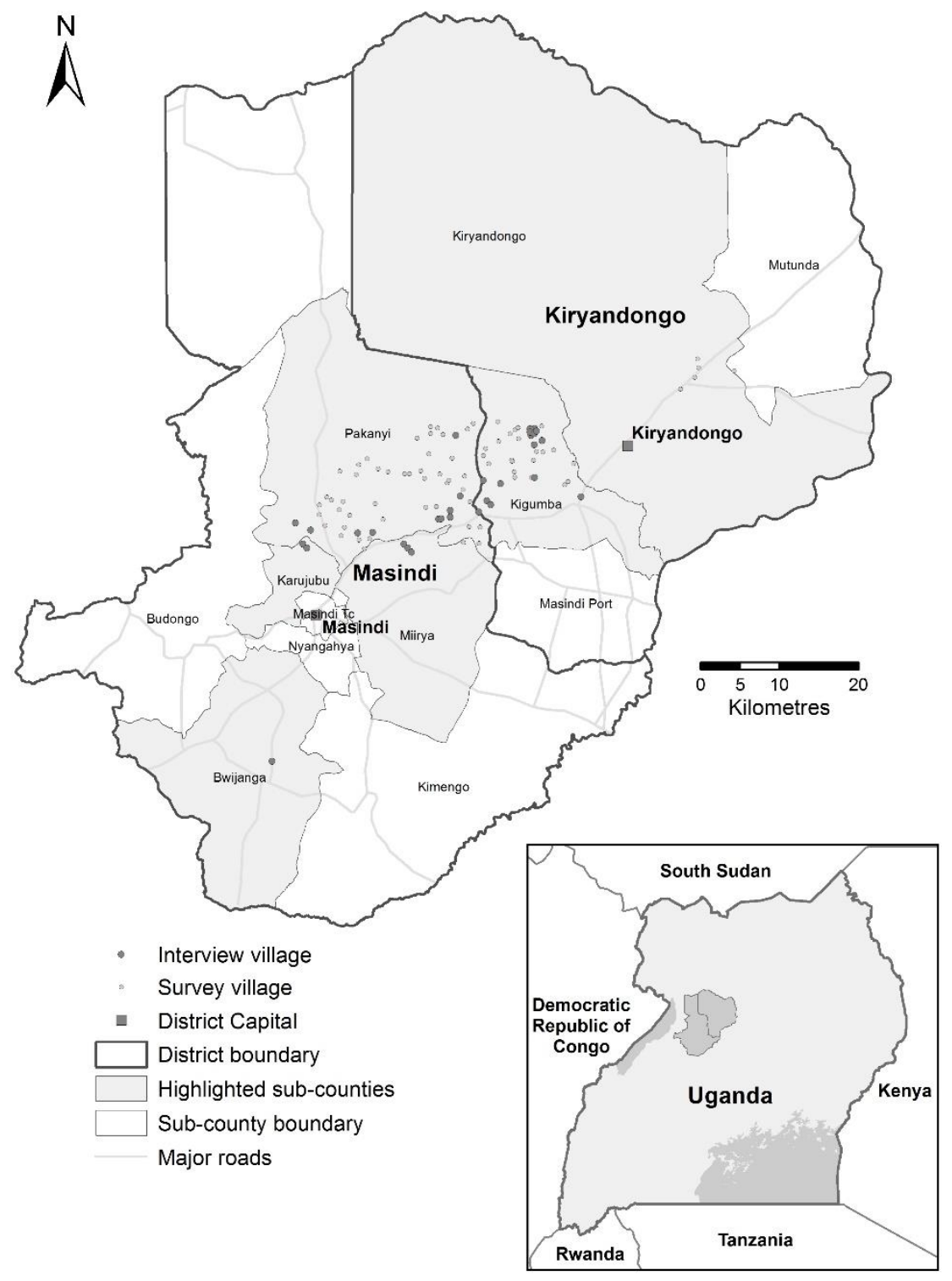

Table 3

Breakdown of maintenance expenditures (Adapted from Burr and Fonseca 2013, p. 63.)

\section{Cost components of}

maintenance

- Minor maintenance and repairs

Expenditure on labour and materials needed for routine maintenance

- Major maintenance Renewal, replacement and rehabilitation costs

- $\quad$ Total estimated costs per annum

*US\$ $1=2850$ UGX
Estimated costs per SHDW per annum

85,500 UGX (US\$ 30) Estimated costs per deep BH per annum

171,000 UGX (US\$ 60)

256,500 UGX (US\$ 90)

342,000 UGX (US\$ 120)

342,000 (US\$ 120) 
When initial formalities are complete, a general village meeting is convened. According to NGO staff, the attendance varies from village to village:

"Sometimes you are forced to do spot mobilisation, otherwise there will not be enough people" (NGO staff member 29 October 2014).

An NGO staff member explains the requirements of the project, and to foster a sense of ownership, each village has to contribute construction materials or cash (to the value of US\$100). The local government requires a payment of 100,000 UGX (US\$ 35) for a shallow well and 200,000 UGX (US\$ 75) for a deep borehole, in the belief that upfront monetary contributions demonstrate the community's willingness to maintain the handpump.

At the meeting, an NGO staff member facilitates the election of a six-strong WUC with a woman preferred in the treasurer's role, because they are locally deemed more trust worthy with funds. Occasionally, selected community members refuse to be part of the WUC: "Sometimes people argue they are too busy" (NGO staff member 10 November 2014).

The NGO remains in contact with a representative from the village to ascertain the construction materials are in place, otherwise "people forget about the application" (NOG staff member, 12 November 2014). Moreover,

"[m]aybe one out of the 20 villages would call you back and tell you that they are ready" (5 November 2014).

A suitable site for construction of the SHDW is then selected by technical staff, and with the landowner's consent the agreement to proceed is signed.

\subsection{Construction phase}

The NGO requires participation in the construction from a minimum of five community members in order to proceed. Weekly checks are carried out on progress with the project and with the obligatory construction of pit latrines (not a requirement of local government constructed sources). Nine out of 22 construction sites required remobilisation between January and October 2014. A site visit where there were no delays (Kinyara I Kamugiri, 29 October 2014) revealed that 22 households out of 40 were unwilling to help in construction, and recently elected WUC members lacked commitment necessitating further elections. A NGO staff member said:

"In most villages we need to push the community members to participate" (10 November 2014).

After construction, the NGO trains each WUC for half a day in basic administration and bookkeeping, leaving contact details of the Hand Pump Mechanic and price lists for spare parts. By contrast, not every water point constructed by the local government has a trained WUC, due according the District Water Office to financial constraints:

"Officially, the training for the water point needs to be two days. However, facilitation is expensive. We only have a budget of 24,000 UGX per training......If 
you are there from 10 am in the morning until $4 \mathrm{pm}$ in the afternoon people will ask for food and maybe even for facilitation ${ }^{7 ”}$ (15 June 2014).

Only when all households have access to a latrine (which may take over a year) will the NGO attach the handle of the handpump. After a warranty period of six months, water users are responsible for O\&M. It is at this stage that the WUC should convene a village meeting with the LC1 to agree on the payment schedule of the water user fee, rules of use and sanctions. The local NGO advises communities to pay 1,000 UGX (US\$ 0.35) per month based on predicted maintenance costs for the average handpump). Ultimately the decision rests with the WUC, and our study indicates considerable variety in the amount and timing of payment. ${ }^{8}$ For the majority of studied sources, it was agreed that users should pay the caretaker; in others, payment is to be made to the treasurer or chairman.

Our study revealed that graduated sanctions for non-payment varied from a warning, to public shaming, a fine of 1,000 UGX, confiscation of a jerry can to refusal of access to the water point. Most sanctions (locally termed byelaws, yet not legally binding) were verbally agreed upon during the meeting and not written down. As all these arrangements were locally determined for each handpump, in the case of a large village with several sources and WUCs, there can be different approaches to fee timing and collection, and several different sets of rules and sanctions.

\subsection{Post-construction}

Data from our WUC survey and interviews with in total 100 WUCs (graphically represented Table 4) revealed that only three water sources (i.e. 3\%) had sufficient fees to pay for major repairs, and only a further twenty had enough funds for minor repairs. The majority - 77 sources - either had insufficient funds for even minor repairs ( 24 sources) or no funds at all -53 sources. $^{9}$

Our study indicated that the long-term sustainability of the majority of the water points was at risk due to lack of maintenance funds. "Most [water sources] break down because the money is not there" commented the DWO for Kiryandongo (August 20, 2013), a view shared by his counterpart for Masindi. Insufficient funds place the communities at risk: for example in Kitengule the handpump broke down and had been out of action for a month when visited in August 2013 because the WUC did not collect water user fees. Those without access to transport were forced to collect water from an open source in the village.

\footnotetext{
${ }^{7}$ The term facilitation is used locally to denote a per diem (covering travel and subsistence) paid to local government officials from government budget. This payment has encouraged community members to similarly request a "sitting allowance" to compensate their time (Jangeyanga, 2013; GoU, 2010).

${ }^{8}$ From US\$ 0,18 to US\$ 0,36 collected per month; to US\$ 0,36 to US\$ 1,08 collected per quarter; to US\$ 1,08 to US\$ 1,16 per semester; and from US\$1,80 to US\$ 3,60 collected per annum.

${ }^{9}$ Out of the twelve government funded water sources in the sample of a 100, three water sources had funds for minor repairs and nine did not collect funds.
} 
Table 4

Funds available for O\&M at 100 water points

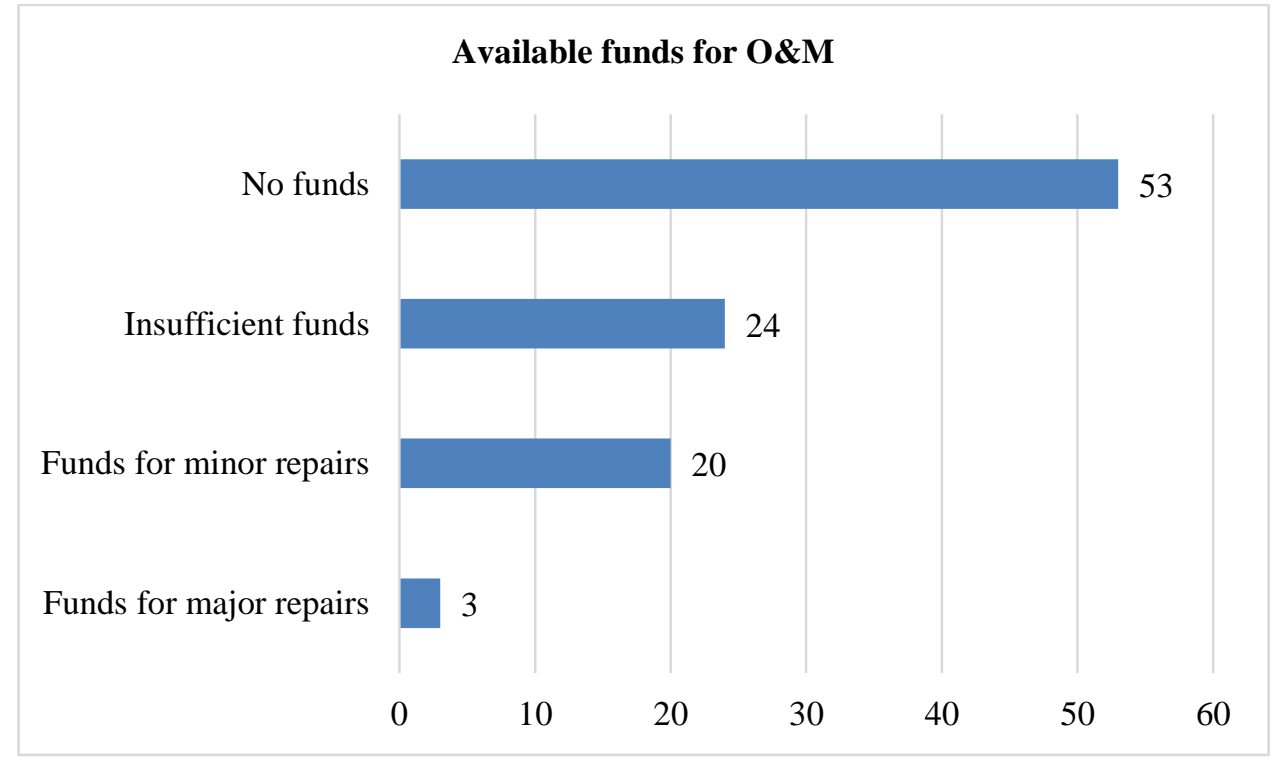

The reasons behind the precarious funding for O\&M, which we have grouped into collective action and enforcement of graduated sanctions, are now explored.

\subsubsection{Collective Action}

In the CBM model, collective action is envisaged through (1) the payment of the water user fee (2) the participation in public meetings about the water point and (3) the voluntary participation of public representatives on the elected WUCs.

\subsubsection{Payment of water user fee}

According to the water user survey and interview data, ${ }^{10}$ the collection of the water user fee was done in a regular fashion at only five water points out of 40. Irregular payment meant that both the water users and the WUC did not structurally adhere to the agreed payment scheme. From the water user survey of thirteen water sources there was collective irregular payment at three sources, collective non-payment in a further three, at six sources there were payment differences amongst users and only at one source formally agreed collection rules were realised.

The study also indicates discrepancies between verbal indications of payment in the water user survey and the inspection of register books, which revealed that in reality the majority of households in the case study were not paying or only doing so very erratically. For example in Kyakamese village, out of 56 households, 30 were defaulting or paying irregularly.

We explored whether affordability was an issue in our case study. Aside from a small group of listed vulnerable households (widow, elderly and disabled) exempted from

\footnotetext{
${ }^{10}$ There is an overlap of three between the two data sets.
} 
payment, community members who were not paying admitted: "one cannot fail to pay 1000 shillings [US\$ 0.35] (community member in Kyakamese, 13 June 2014)." Nevertheless, several community members raised the timing of payment, particularly the period leading up to harvest. The DWO of Kiryandongo, however, viewed these as "just excuses". He said:

"One of our biggest diseases in this country is that people want everything for free. Just talking and explaining that they should pay for a service is not enough. They need some force behind them" (16 June 2014).

Our research identified seven reasons, which varied by source, why water users were not willing to pay the water user fees. The first justification for non-payment was that community members felt they had already paid at the construction phase.

Second, suspicion of the misuse of funds by WUC members was frequently cited. A community member in Kihaguzi said:

"People feel their money will be eaten by the committee members. This feeling of being cheated is increased if the handpump is not breaking down for some period. Then, people start to wonder where their money is going." (25 June 2014)

Suspicion increases when collection is undertaken by several WUC members. In one instance 250,000 UGX (US\$ 88) was syphoned off by the treasurer to repair his motorbike, with the result that there was no money for repairs when the pump broke almost immediately. Understandably the preference of many is to pay at the time of breakdown.

The third reason was the availability of other water sources (nearby protected water points or open contaminated ponds) where community members were able to collect water without paying. Indeed, despite health warnings by the NGO and health workers some people preferred the taste of swamp water, and ensuing sickness was attributed to witchcraft.

The households that were willingly paying water user fees were often educated:

"These twenty (households who pay) are literate. They have moved. They are educated. They know the importance of clean water" (LC I, Kyarutanga 10 November 2014).

The fourth reason for non-payment was the pre-existing tensions between community members prior to construction. In Kidwera II, disputes over land and income disparities between households contributed to animosities compounded by the refusal of more affluent households, who are often elected to the WUC, to subsidise the poorer households. The Kyakamese WUC secretary said:

"People assume that I have more money as I am a teacher, and they expect me to pay for them" (13 June 2014). 
The result of these tensions is a lack of willingness among community members to cooperate:

"People don't want to work together. People cannot sit on the same table and discuss issues about water" (WUC chairperson of Kidwera II 10 November 2014).

The fifth reason for non-payment was the expectation of external support by the local government or the NGO. Our findings question the assumption that contributing to construction would generate a sense of ownership and a feeling of responsibility for maintenance. In Kitengule a community member for example said:

"This water source was built by the white men, so why should we pay when the water source breaks down?" (10 August 2013).

The sixth explanation was that community members were aware that the WUC or the LC1 were not able to enforce the graduated sanctions for non-payment. As we will discuss shortly, the WUC or the LCI rarely enforced these byelaws as they could create conflicts between households, so free-riding continued without risk of punishment. The seventh and last reason for people not to pay the water user fee was the realisation that free-riding neighbours were not penalised, encouraging more to follow suit i.e a snowball effect.

\subsubsection{Community participation in public meetings and public works}

Our interview data uncovered weak community engagement in both public meetings about water management, and in public works to keep the water sources clean at the majority of water points studied. Regular public meetings about the water source were not convened by the majority of WUCs studied. At Kyarutanga I a WUC member explained:

"Maybe around ten people will come. They feel they are wasting their time" (13 November 2014).

In most cases public meetings were only organised at times of breakdown and most respondents in the interview data prioritised their livelihood needs above attending public meetings:

"During these WUC meetings, they only talk about paying water user fee. So, why should I go to a meeting that is only costing me money?" (Interview community member Kidwera II, 10 November 2014).

Similarly, for cleaning obligations at the water points. The WUC Chairman of Nyakable-Ausonzi said: "Normally they don't want to work together at the water source. They don't want to clean and respond" (6 August 2013). The treasurer in Kyakamese declared:

"As people are paying they also feel that they should not work at the water source. But now the problem is that so many people don't pay at all" (13 June 2014). 
However, a variable picture emerges. At four water points (Nyakasakazi, KihondaNyakachaki, Abira, Kidwere I), the WUC organised regular well-attended community meetings.

\subsubsection{The voluntary participation of the Water User Committee}

We now identify a range of challenges concerning the functioning of the WUC. Collecting the water user fee in most villages was a time-consuming and frustrating process, illustrated by the following:

"If a person does not want to pay, he will not tell you direct. He will say my child is sick. We can go back many times ... until there are many times" (WUC member, Kyarutanga I 13 November 2014).

Several interviewed WUC members recounted tales of being regularly threatened when they tried to collect water user fees. The caretakers of sources in Mpumwe and Nyakatugo reported that women threatened to bewitch them. Many became resigned and ultimately non-confrontational with habitual non-payers.

However, escalating harassment resulting in WUC members resigning their posts:

"I stopped to be part of the WUC. There were some people who threatened me to beat me up when I asked for money" (Former caretaker Kyarutanga II, 13 November 2014).

All the studied WUCs had lost several members, through resignation or migration, and none had the specified number. Those that remained often devoted little time to their virtually symbolic role, using the voluntary nature of the work as justification, which they also used as an excuse to access WUC funds for their personal use: the treasurer in Kitengule admitted that other members of the WUC "[c]ome at different times to look for money - it gets lost and consumed" (9 August 2013). In Mpumwe, the former Chairman of the WUC said:

"The retired WUC members heard 1,000 shillings [is to be collected]. They thought there was some eating, but then they found no money, so no eating. They retreated from the committee" (5 August 2013).

Despite the turnover, at most water points one or two WUC members remained active: in Nyakabale-Ausonzi the Chairman admitted that "[b]asically we don't have a committee" - the only active members were himself and the caretaker (6 August 2013). The DWO of Kiryandongo wryly observed that: "[o]ne person becomes a committee" (20 August 2013). The case study NGO tried to reinvigorate inactive WUCs or promote the elections of new members. The 'WUC survey' showed that over a third $(35, \mathrm{~N}=84)$ of the WUCs were re-elected under the auspices of the NGO because they were not carrying out their roles satisfactorily or had resigned. 


\subsubsection{Enforcement of graduated sanctions}

WUCs were not able to enforce even the lower grades of sanctions, such as public shaming and confiscation of jerry cans, on community members for non-payment. We identify four reasons for the difficulties in enforcing sanctions. First, the WUCs at all the water points apart from two (Abira and Kihonda-Nyakachaki) did not know how many households were using the water point. From our interviews it was clear households used multiple sources, often crossing village borders dependent on convenience. Temporary settlers further confused the picture.

Second, the WUC members' social standing in the community was adversely affected by enforcing the byelaw: "[t]his could only bring hatred in the village" (WUC member Kidwera 1, 10 November 2014), and in Mboira village:

"People have a negative attitude against the person that enforces the byelaw. You become a public enemy" (WUC member, 30 October 2014).

The threats WUC members received from transgressors, physical or psychological, weakened their resolve to enforce the byelaws.

A third reason was the fear of destabilising relationships with relatives and friends. For example, at one water point, community members accused the caretaker of failing to collect money from his friends. Equally: "[i]t becomes hard to enforce a byelaw on your relative" (WUC member Kyarutanga, 30 October 2014). Further: "[w] hat do you do if someone pleads with you and tells you he has no money?" (WUC member Mpumwe, 19 June 2014).

A fourth reason was the WUCs felt they lacked authority and were not adequately supported in their efforts by their village councillor (LC I) who did not want to compromise re-election prospects. Recourse to external bodies such as the sub-county to follow-up with defaulters was commonly raised. However, an identified problem was that government officials usually needed to be paid. ${ }^{11} \mathrm{~A}$ WUC member in Kyakamese explains:

"Maybe I should say the system has really defeated us. If you get an officer from the sub-county, you need to give them something to move. Yet, our money is not enough. We did it once, but we realised the very people who were helping us were instead dwindling our account" (13 June, 2014).

The only other authority that was left in our case study was the NGO. However, in reality it was beyond the scope of the NGO to enforce sanctions: "staff don't want to be the dictator in the village" (NGO staff member, 6 August 2013).

\footnotetext{
${ }^{11}$ Due to government budget shortages, per diems are often not paid so local officials expect community members (or NGOs) to cover their per diem.
} 
Interestingly, although sanctions on the payment of water user fees were not enforced, the majority of the villages did enforce sanctions for non-participation in road works in accordance with locally devised and longstanding, yet not legally binding, byelaws.

"Maintaining the road is done from time immemorial. That is why everyone comes and if not, people will come and make you pay or confiscate a goat." (NGO staff member, 5 November 2014).

Despite this discouraging picture, six water points in four villages in our interview data were successful in raising funds for O\&M. In the following section we describe these cases.

\subsection{Alternative water user fee collection approaches}

Isolated Abira village with one source, with the next nearest water point $3 \mathrm{~km}$ away, successfully raised adequate water user fees for O\&M which were stored on a mobile money account. All the households cooperated together as they belonged to the same clan (LCI, 11 November 2014). The WUC chairperson (also the LCI) commanded respect in the community because he was the grandson of the late king of his tribe and the village had a history of enforcing sanctions for non-compliance with rules: "[p] eople know the sanctions [for free-riding] and fear to be arrested" (LCI, 11 November 2014). The three facets of collective action (regular payment, maintaining the area around the source, and attending and participating in public meetings) were adhered to in this village.

As is the case in Abira, the single water point in Kihonda-Nyakachaki village is isolated from other sources (1.5 km away) and has a respected WUC chairperson committed to collecting user fees (stored in a bank account) despite harassment:

"People abuse us... but at the end we get the money" (WUC chairperson, 10 November 2014).

The three water points in densely populated Bisenye experience high demand, resulting in significant wear and tear on the handpumps which necessitated the formulation of rules to govern access and enforcement. The sources were managed by caretakers who developed a two-tier annual payment scheme collected in January: standard and a priority access "VIP line". The standard line often meant a lengthy queue for water, where as the VIP payers were entitled to go straight to the head of the queue (WUC member 12 November 2014). Zealous caretakers were paid out of water user fees and enforced shaming misuse sanctions, including public caning. Still there were insufficient funds to cover possible major repairs for each water source, attendance at community meetings was poor, handpump vandalism took place and caretakers were threatened.

An alternative scheme for generating maintenance funds was instigated by an entrepreneurial member of the WUC in Kidwera I: he proposed to invest the collected meagre 90.000 UGX (US\$ 19) in seeds to plant maize on one acre of his family land. The community tended the crops, and profits of the harvest $(405,000$ UGX or US\$ 
131) were stored in a locked money-box held by the initiator of the scheme who was locally trusted. In this village, people were willing to work collectively and attended community meetings, and the need to collect funds directly was circumvented. It is noteworthy that this strategy was rejected by the adjacent village.

These approaches, which resulted in regular payment and enforcement of sanctions, may not be easily replicated in other villages due to unique circumstances such as strong leadership, water scarcity, historical patterns, organic organisation and the provision of an incentive.

\section{Discussion}

Despite close attention to CBM good practice (Doe and Khan, 2004) sustainable outcomes did not materialise for NGO constructed points, nor for those constructed by the government. In this discussion we suggest that the wings of the CBM model individually and collectively are contributing to the multiple failings observed in our case study.

\subsection{Problems arising from neo-liberal inspired commodification}

The CBM model expects the beneficiaries of significant capital investments to make a monetary contribution (5-10\% of total cost) at the outset, and thereafter to continue with affordable on-going payment to cover O\&M for sustainable access to water ('the goods'). This is the extent to which commodification has been applied under the CBM model. It is assumed that the initial contribution would generate a sense of ownership that would instil a commitment to pay indefinitely, a small charge for water use - a reasonable enough requirement. Marks and Davis (2012) demonstrate that a sense of ownership and obligation does follow on from an investment - on an individual basis - but here we are dealing with the collective where such feelings may be diluted. The fact is willingness to pay for maintenance has not materialised in our case study. Just $3 \%$ of the surveyed water points (see Table 4) had sufficient funds for major repairs, with barely half $(47 \%)$ collecting any funds at all. This alarming failure to secure payment has threatened the long-term functionality of the water sources which supports the findings of Burr and Fonseca, 2013 and Jones, 2011. There is a firm conviction amongst participants that they have already paid in the form of the initial contribution. Moreover, a degree of confusion exists over what the water user payment is actually for: groundwater, after all, is untreated and free. What is not always fully grasped is that mechanical devices require maintenance and repair, and without ready funds, there is likely to be a lengthy interruption to supply, as witnessed in Kitengule village.

Commodification necessitates the collection of money from users, and this has proved highly damaging to social relations. WUC members have been reluctant to destabilise friend and family connections, chase debtors and subject themselves to abuse while 
carrying out voluntary duties. This is the point when commodification begins to extend from 'the goods' to 'the service' of water provision. ${ }^{12}$ Those WUC members who do not resign (or refuse to become involved in the first place) feel that in many cases they deserve recompense in the form of payment for the unpalatable task they take on, or failing that, they consider they are justified in abusing funds for personal expenditure. A stage further in commodification is the situation where WUCs have effectively abandoned attempts to discipline debtors and free-riders and have looked for external sanctioning support from local government (sub-county level). The case study illustrates that WUCs have effectively been required to pay for this service from their collected water user fees. The paying of per diems to already salaried officials is a conspicuous example of commodification encroaching on rule enforcement which was originally intended to be a voluntary undertaking. The CBM approach is being seriously undermined by the relentless, probably irreversible, march of commodification.

\subsection{CPR theory, grass-roots romanticism and the messy reality}

The CBM model is based on warm and cosy conceptualisations of community (Mohan and Stokke, 2000; Brown 2013). Our case study supports Cleaver's (2001) more nuanced understanding of the term community as "the site of both solidarity and conflict, and shifting alliances" (p.45) which we argue impacts on the viability of collective action.

An integral part of CPR theory is the formation of self-regulating institutions whose business is to build trust and norms of reciprocity, and more specifically to devise appropriate rules of usage and enforce sanctions on those who break them in order to ensure the sustainability of an undertaking. It is key to recognise that successful cases of CPR management, as documented by Ostrom (1990), mostly arose organically and were independently organised. The rural water projects were neither: they were government policy and communities have never been organised around water, so no set of long standing customs and traditional penalties are in place. ${ }^{13}$

Despite the full range of participatory strategies put in place by the implementing NGO, water users were disinclined to attend public meetings or volunteer their services for the upkeep of the water point, which supports the findings of Harvey (2007), Lockwood and Smits(2011) and Quin et al.(2011). Further, continuous pressurising and motivating by the NGO implementer became necessary and ironically, their well-intentioned presence may weaken feelings of responsibility for the handpumps. Villages often have multiple water sources, so in reality users can avail themselves of alternatives, which further erodes a sense of loyalty to a particular water point.

\footnotetext{
${ }^{12}$ Even in villages where caretakers were formally paid for their services, such as Bisenye, it did not guarantee that sufficient funds for maintenance were collected.

13 In the case study, two villages, Kidwera I and Bisenye, independently devised alternative approaches to generate maintenance funds that matched the needs in their locality.
} 
Fundamental to CPR theory is that households eligible to use the source are clearly defined, but people bounded in the same geographical area are not static (Guijt and Shah 1998) as our case study indicates. The messy reality is that WUCs did not know which households used a particular water point due to migration, short-term residency or the practice of using multiple water sources within and across village borders. Domestic water also differs from other CPR schemes because payment for use is involved, and because it is a basic Human Right it has proved morally difficult to deny access. This lack of clarity had repercussions for payment and the imposition of sanctions, and fundamentally contravenes Ostrom's first design principle 'clearly defined boundaries'. The fact that byelaws are verbal and differ for each point is also unhelpful.

In addition to overseeing rotas for cleaning and opening and locking the pumps, WUCs are tasked with collecting money from reluctant contributors and enforcing discipline for failure to pay. This is where the neo-liberal paradigm and commodification of water ('the goods') has sullied ${ }^{14}$ the potential of collective action and has become socially divisive, often exacerbating pre-existing tensions. The potential to access the collected fees has proved corrupting in some instances. In collectively managed schemes, the lines of responsibility and accountability to users, particularly in relation to fee collection, become blurred, as our case study exemplifies. Mistrust of WUC members over money, often justified, has in many cases undermined collective action.

As a result of embedded social networks and fractured relations in the villages, the real situation is that WUCs have no authority, and their self-regulating status is negated once calls to local government are made. Ultimately, WUCs have been unwilling and unable to uphold the system, and constant re-election and reinvigoration by NGOs has had little impact. Citizens are aware that sanctions cannot be enforced on water access, thus contravening CPR theory. Non-payment has become a rational choice and the norm, and has fatally undermined the CBM model.

The two wings of the CBM model do not work comfortably together, and both have relied heavily on assumptions about human behaviour, which we argue do not bear out in the Ugandan or wider contexts (Brown, 2011; Cleaver, 1999). CPR theory does not reflect messy rural realities, and payment for water compounds social tensions and undermines the potential for sustainable collective action.

\subsection{Evaluating the recommendations in the existing literature}

While it is increasingly recognised there are difficulties with the CBM approach, attempts to address failings tend to focus on shoring up the CBM paradigm and can be

\footnotetext{
${ }^{14}$ Harvey (1996), building on Freud, graphically reminds us of the corrupting influence of money and its association with filth.
} 
grouped under three categories: increasing social capital, via technology, and via external help. The question under review is whether these approaches are likely to increase involvement and willingness to pay?

The advocates of community management set great store by investing in and increasing the stock of social capital via participation and capacity building, but this is an open ended, ever-extendable and expensive endeavour requiring trained and funded facilitators. Whether the sustainability of CBM can be improved in this way is questionable. Our findings indicate that problems arising from the voluntary status of WUCs, the availability of alternative sources, and the reluctance to enforce sanctions on family and friends are unlikely to be resolved by such expenditure of time and money, nor is it likely to stimulate a willingness to pay.

The case study demonstrated the lengths to which the NGO went in motivating the application process, getting the participatory process right and reinvigorating failing WUCs. Our interpretation is that there is very little more that they could have done.

There was scant evidence that the NGO efforts resulted in social cohesion because deep-seated divisions based on wealth and education are not easily bridged by tweaking participatory processes (Brown, 2014). Our findings suggest first, that the constant intervention by the NGO may be eroding the sense of local connection and thus responsibility to the project. Second, and perversely, that pockets of close social relations involving friends and family members of the WUC may actually inhibit the collection of fees and enforcement of rules. Thus ironically, attempts to increase the stock of social capital in these villages as frequently suggested (Bisung and Elliott, 2014) may only exacerbate these problems.We acknowledge that there is value in practical training in skills such as record keeping, financial management and knowledge about water-borne diseases, but such training would need to be paid for, and attendance cannot be guaranteed.

There is a belief in some quarters that technological solutions such as sensors to predict imminent breakdown and communicate failure to mechanics will reduce downtime (Hope et al., 2011; Hutchings et al., 2012; Thomson et al., 2012). While we do not pass judgement on the merits of these innovations (de Laet and Mol, 2000), the cost of retrofitting the handpumps is significant and at bottom we do not think that the lack of information about the functioning of a handpump is the limiting factor behind low levels of payment, or enforcement of sanctions.

In the literature (Barnes et al., 2014; Baumann and Furey, 2013; Carter et al., 2010; Harvey and Reed, 2006; Kamruzzaman et al., 2013; Kleemeier, 2010; Lockwood, 2004; Moriarty et al., 2013; Schouten and Moriarty, 2003) and in the communities studied there were calls for external support to enhance sustainability. We noted in the literature review post-construction support has become pre-requisite in project 
planning. ${ }^{15}$ While Koestler et al. (2010) advocate local government as the logical provider of external support, the lack of funds and capacity (Day, 2011; Kleemeier, 2010) and the cloud of corruption (Blundo and Le Meur, 2009) are an obstacle to this route, and capacity building of local government itself is considered vital (Quin et al., 2011).We argue the calls from both academics and community members for external support are a strong signal that the model is not working. Many of the WUCs recognised they were not self-regulating institutions because they were unable to raise the necessary funds and enforce sanctions.

\section{Conclusion}

The solution to the effective maintenance of handpumps is proving a formidable challenge, and central to achieving the sixth post-2015 Sustainable Development Goal are questions over who should finance the running costs of rural water points. It has been demonstrated conceptually and empirically that there are problems with commodification and within grassroots approaches, and collectively the CBM model is undermined once the voluntary service of the WUC moves towards commodification. Reforms within the CBM paradigm do not offer any guarantee of improved outcomes - they do not overcome the central failings of willingness to pay and to participate. In sum the CBM model has turned out to be a blueprint for breakdown.

It seems we are at a crossroads in rural water delivery and need to look squarely at the question: can communities be financially responsible for maintenance, and should they be responsible? The impression from extensive fieldwork is that there is little appetite for it: there is no evidence that communities want full citizen control (Golooba-mutebi, 2005).

Will academics, policy makers and practitioners be open to explore alternatives that go beyond the CBM paradigm? A return to the state-led paradigm and cross subsidisation (Swyngedouw, 2006), despite its history of poor provision, may be ideologically appealing to some. Advancing self-supply such as rain water harvesting is another option that has been advocated (MWE, 2011). Finally, the growing trend towards commodification may point in the direction of privately managed rural water points (Carter and Kidega, 2013; Harvey, 2008; Harvey et al., 2006; World Bank, 2010). These are possibilities we explore in subsequent papers, for we firmly believe that until there is a resolution to financing handpump maintenance, the sixth post2015 Sustainable Development Goal is but a mirage.

\section{Acknowledgments}

We would like to thank the three anonymous referees and the editor for their extremely constructive comments on earlier versions of the paper. The fieldwork undertaken in Uganda was made possible through the Department of Geography at the University of Portsmouth.

\footnotetext{
${ }^{15}$ The ultimate responsibility for the source, however, remains vested with the community.
} 


\section{References}

Bakker, K.J., 2003. An Uncooperative Commodity: Privatizing Water in England and Wales. Oxford University Press.

Barnes, R., Nicholas, A., Roser, D., Brown, P., 2014. Implementing sustainable rural water and sanitation projects in rural, developing communities. Waterlines 33 (1), 71 99.

Baumann, E., 2006. Do Operation and Maintenance Pay? Waterlines 25 (1), 10-12. 〈http://www.ircwash.org/sites/default/files/Baumann-2006-Do.pdf $>$ (accessed 02.02.2015).

Baumann, E., Furey, S., 2013. How Three Handpumps Revolutionised Rural Water Supplies. A brief history of the India Mark II/III, Afridev and the Zimbabwe Bush Pump. Rural Water Supply Network. Field Note (1). <http://www.rural-watersupply.net/_ressources/documents/default/1-475-2-1363951079.pdf $>$ (accessed 02.02.2015).

Bhandari, B., Grant, M., 2007. User satisfaction and sustainability of drinking water schemes in rural communities of Nepal. Sustainability: Science, Practice, \& Policy 3 (1), 12-20. <http://www.google.nl/archives/vol3iss1/0604-017.bhandari.html>

Bisung, E., Elliott, S.J., Schuster-Wallace, C.J., Karanja, D.M., 2014. Social capital, collective action and access to water in Rural Kenya. Social Science \& Medicine 119, 147-154. DOI: 10.1016/ j.socscimed.2014.07.060.

Bisung, E. and Elliott, J. S., 2014. Toward a social capital based framework for understanding the water-health nexus. Social Science and Medicine 108, $194-200$. DOI: 10.1016/j.socscimed.2014.01.042.

Blaikie, P., 2006. Is small really beautiful? Community-based natural resource management in Malawi and Botswana. World Development 34, 1942-57.

Blundo, G., Le Meur, P., 2009. The Governance of Daily Life in Africa: Ethnographic explorations of public and private services. African social studies series. BRILL, Leiden.

Breslin, E.D., 2003. Demand response approach in practice: why sustainability remains elusive. Water Aid. Paper presented at the 3rd World Water Forum, Japan. <file:///C:/Users/Lenovo/Downloads/demand-responsive-approachsustainability\%20(3).pdf> (accessed 02.02.2015). 
Briscoe, J., and D. Ferranti., 1988. Water for Rural Communities, Helping People Help Themselves. Washington, DC. World Bank.

<http://johnbriscoe.seas.harvard.edu/files/johnbriscoe/files/2._briscoe_-_de_ferranti_helping_people_help_themselves-_world_bank_1988.pdf> (accessed 02.02.2015).

Brown, J. 2011. Assuming too much? Participatory water resource governance in South Africa. The Geographical Journal 177 (2), 171-185. DOI: 10.1111/j.14754959.2010.00378.x.

Brown, J., 2013. Can participation Change the Geography of Water, Lessons from South Africa? Annals of the Association of American Geographers 103 (2), 271-279. DOI: $10.1080 / 00045608.2013 .754685$.

Brown, J., 2014. 'Evaluating participatory initiatives in South Africa: not just processes but outcomes too' SAGE Open, vol 4, no. 2. DOI:

$10.1177 / 2158244014531966$

Burr, P., Fonseca, C., 2013. Applying a life-cycle costs approach to water. Costs and service levels in rural and small town areas in Andhra Pradesh (India), Burkina Faso, Ghana and Mozambique. IRC International Water and Sanitation Centre. Working paper 8 .

Carter, R., Tyrrel, S., Howsam, P., 1999. Impact and sustainability of community water supply and sanitation programmes in developing countries. Water and Environment Journal, 13 (4): 292-296.

<http://www.researchgate.net/profile/Richard_Carter6/publication/2395919_Impact And_Sustainability_Of_Community_Water_Supply_And_Sanitation_Programmes_In _Developing_Countries/links/0fcfd5093542495620000000.pdf>

Carter, R.C., Harvey, E., Casey, V., 2010. User financing of rural handpump water services. Paper presented at IRC Symposium, Pumps, Pipes and Promises. <http://www.ircwash.org/resources/user-financing-rural-handpump-water-servicespaper-presented-irc-symposium-\%E2\%80\%98-pumps-pipes > (accessed 02.02.2015).

Carter, R.C., Kidega, G., 2013. Assessment of the sustainability of water and sanitation services set up as part of the WaterAid/EUWF post-conflict project in Uganda. Water Aid. <http://www.wateraid.org/ /media/Publications/Sustainabilityof-WASH-services-supported-by-WaterAid-in-Uganda.pdf $>$

Cleaver, F., 1999. Paradoxes of participation: questioning participatory approaches to development. Journal of International Development 11, 597-612. 
Cleaver, F., 2001. Institutions, agency and the limitations of participatory approaches to development. In: Cooke, B., and Kothari, U. (Eds.) Participation: The new tyranny? Zed Books, London, pp. 36-55.

Coleman, J.S., 1988. Social capital in the creation of human capital. American journal of sociology 94, S95-S120.

Cooke, B. and Kothari, U., 2001. Participation the new tyranny? Zed Books, London.

Day, J., 2011. Options for water resource management. In: The Institution of Civil Engineers, Oxfam GB, WaterAid. (Eds.) Managing water locally. An essential dimension of community water development, pp. 18-24.

De Laet, M. and Mol, A., 2000. 'The Zimbabwe Bush Pump: Mechanics of a Fluid Technology. Social Studies of Science 30 (2), 225-263. DOI:

$10.1177 / 030631200030002002$

Doe, S. R., Khan, M. S., 2004. The boundaries and limits of community management: Lessons from the water sector in Ghana. Community Development Journal, 39 (4), 360-371. DOI:10.1093/cdj/bsh032

Evans, P. 1992. Paying the piper: An overview of community financing of water and sanitation. Delft: IRC International Water and Sanitation Centre.

Fritz, F., Menocal, A.R., 2006. (Re)building Developmental States: From Theory to Practice. Working paper 274. Overseas Development Institute.

<http://www.odi.org/sites/odi.org.uk/files/odi-assets/publications-opinionfiles/2328.pdf>

Golooba-Mutebi, F., 2005. Witchcraft, Social Cohesion and Participation in a South African Village. Development and Change 36 (5), 937-958.

Golooba-Mutebi, F., 2012. In search of the right formula: public, private and community driven provision of safe water in Rwanda and Uganda. Public Administration and Development 32 (4-5), 430-443. DOI: 10.1002/pad.1638.

Government of Uganda (GOU), 1995. Constitution of Uganda.

Government of Uganda (GOU), 1997. The Local Government Act. Ministry of Local Government, Uganda.

Government of Uganda (GoU), 1999. National Water Policy. Ministry of Water and Environment, Uganda. 
Government of Uganda (GoU), 2010. The Ugandan Public Service Standing Orders.

Guijt, I., Shah, K. M., 1998. The Myth of Community, Intermediate Technology Publications, London.

Harvey, D., 1996. Justice, Nature and the Geography of Difference. Blackwell, Oxford.

Harvey, P.A. and Reed R.A., 2006. Community-managed water supplies in Africa: Sustainable or dispensable? Community Development Journal 42 (3), 365-378.

Harvey. P, Uno, J., Reed, R., 2006. Management of rural water services in subSaharan Africa. Proceedings of the ICE - Civil Engineering 159 (4), 178 -184. DOI: $\underline{10.1680 / \text { cien.2006.159.4.178 }}$

Harvey, P.A., 2007. Cost determination and sustainable financing for rural water services in sub-saharan Africa. Water policy 9: 373-391.

$<$ http://media.greennexxus.com/wasrag/Articles_of_Interest/Water_Supply/Operation s_and_Maintenance/Cost_Determination.pdf> (accessed 02.02.2015).

Harvey, P.A., 2008. Poverty Reduction Strategies: opportunities and threats for sustainable rural water services in sub-Saharan Africa. Progress in Development Studies 8, 115-128. < http://pdj.sagepub.com/content/8/1/115.refs > (accessed 02.02.2015).

Holmes, T., Scoones, I., 2000. Participatory environmental policy processes: experiences from North and South. IDS Working Paper 113, Institute for Development Studies, Brighton. <https://www.ids.ac.uk/files/Wp113.pdf> (accessed 02.02.2015).

Hope, R., Foster, T., Money, A., Rouse, M., Money, N. and Thomas, M., 2011. Smart Water Systems. Project report to UK DFID, April 2011. Oxford University, Oxford.

Hutchings, M., Dev, A., M., Palaniappan, M., Srinivasan, V., Ramanathan, N. and Taylor, J., 2012. mWASH: Mobile Phone Applications for the Water, Sanitation, and Hygiene Sector, Pacific Institute \& Nexleaf Analytics, Oakland, CA.

Jangeyanga, P., 2013. Life-Cycle Cost Analysis of Rural Water supply in Uganda Kabarole District. Triple-S Uganda, IRC International Water and Sanitation Centre. 
Jiménez, A., Pérez-Foguet, A.,2010. Challenges for Water Governance in Rural Water Supply: Lessons Learned from Tanzania. International Journal of Water Resources Development 26 (2), 235-248. DOI: 10.1080/07900621003775763.

Joint Monitoring Program., 2011. Drinking Water Equity, Safety and Sustainability: Thematic report on drinking water.

<http://www.wssinfo.org/fileadmin/user_upload/resources/report_wash_low.pdf> (accessed 02.02.2015).

Jones, S., 2011. Participation as citizenship or payment? A case study of rural drinking water governance in Mali. Water Alternatives 4 (1), 54-71.

<http://www.water-alternatives.org/index.php/allabs/126-a4-1-4/file> (accessed 02.02.2015).

Jones, S., 2013. How Can INGOs Help Promote Sustainable Rural Water Services? An Analysis of WaterAid's Approach to Supporting Local Governments in Mali. Water Alternatives 6 (3), 350-366. <http://www.wateralternatives.org/index.php/alldoc/articles/vol6/v6issue3/221-a6-3-2/file> (accessed 02.02.2015).

Kähkönen, S. 1999. Does social capital matter in water and sanitation delivery? A review of literature. Washington D.C: World Bank.

<http://siteresources.worldbank.org/INTSOCIALCAPITAL/Resources/SocialCapital-Initiative-Working-Paper-Series/SCI-WPS-09.pdf> (accessed 02.02.2015).

Kamruzzaman, A.K.M., Said, I., Osman, O., 2013. Overview on Management Patterns in Community, Private and Hybrid Management in Rural Water Supply. Journal of Sustainable Development 6 (5), 26-36. DOI: 10.5539/jsd.v6n5p26.

Kavuta, A, J., Edriss, A, K., 2015. Incidence of poverty in rural areas of Uganda: do livelihood strategies matter? Journal of Economics and Sustainable Development 6 (5), 53-69.

Kleemeier, E., \& Narkevic, J., 2010. A global review of private operator experiences in rural areas, Private Operator Models for Community Water Supply. The World Bank. <http://www.ircwash.org/sites/default/files/Kleemeier-2010-Global.pdf>

Kleemeier, E.L., 2010. Private operators and rural water supplies: A Desk Review of Experience. Washington D.C: World Bank.

<https://openknowledge.worldbank.org/bitstream/handle/10986/17248/578310revised 010us0record10rpostudy.pdf?sequence $=1>($ accessed 03.02.2015). 
Koestler, L., 2009. Private sector involvement in rural water supply: case studies from Uganda. Paper presented at the $34^{\text {th }}$ WEDC International Conference, Addis Ababa, Ethiopia. Water, Sanitation and Hygiene: Sustainable development and multisectoral approaches.

Krishna, A., Uphoff, N., 2002. Mapping and measuring social capital through assessment of collective action to conserve and develop watersheds in Rajasthan, India. In: Grootaert, C., Bastelaer, T. (Eds.). The Role of Social Capital in Development: an Empirical Assessment. Cambridge University Press, New York, pp. 85-124.

Le Gouais, A. and Wach, E., 2013. A qualitative analysis of rural water sector policy documents. Water Alternatives 6 (3), 439-461. <http://www.wateralternatives.org/index.php/volume6/v6issue3/227-a6-3-7/file> (accessed 02.02.2015).

Lockwood, H., 2004. Scaling up community management of rural water supply. IRC International Water and Sanitation Centre. <http://www.bvsde.opsoms.org/bvsacg/fulltext/scaling.pdf $>$ (accessed 02.02.2015).

Lockwood, H. and Smits, S., 2011. Supporting rural water supply: Moving towards a service delivery approach. Practical Action Publishing, Rugby, UK.

<file:///C:/Users/Lenovo/Downloads/Supporting\%20Rural\%20Water\%20Supply\%20( 2).pdf> (accessed 02.02.2015).

Mandara, C.G., Butijn, C., Niehof, A., 2013. Community management and sustainability of rural water facilities. Water Policy 15, 79-100.

Mansuri, G., Rao, V., 2013. Localizing development: does participation work? Washington, D.C: World Bank.

Marks, S.J. and Davis, J., 2012. Does user participation lead to a sense of ownership for rural water systems? Evidence from Kenya. World Development 40 (8), 15692012. 〈http://woods.stanford.edu/sites/default/files/files/RuralWaterKenya.pdf> (accessed 02.02.2015).

Miller, D., 1980. Self-Help and Popular Participation in Rural Water Systems. Paris: Organisation for Economic Co-operation and Development, Development Centre.

Ministry of Water and Environment, Uganda., 2007. District Implementation Manual. < file:///C:/Users/Lenovo/Downloads/District_implementation_manual2007.pdf> (accessed 03.02.2015).

Ministry of Water and Environment Uganda, Directorate of Water Development., 2011. National framework for operation and maintenance of rural water supplies in 
Uganda.

<file:///C:/Users/Lenovo/Downloads/National\%20Framework\%20for\%200\%20and\% 20M\%20of\%20RWS\%20Uganda\%202011\%20(2).pdf> (accessed 03.02.2015).

Ministry of Water and Environment, Uganda. 2014. Water and Environment Sector Performance Report 2014.

<file://C:/Users/Lenovo/Downloads/SPR\%202014\%20FINAL\%20(1).pdf> (accessed 03.02.2015).

Mohan, G and Stokke, K., 2000. Participatory development and empowerment: The dangers of localism, Third World Quarterly, 21:2, 247-269, DOI:

$10.1080 / 01436590050004346$

Mohan, G., 2002. The disappointments of civil society: the politics of NGO interventions in northern Ghana, Political Geography, 21,125-154.

Montgomery, M.A., Bartram, J., Elimelech, M., 2009. Increasing functional sustainability of water and sanitation supplies in rural sub-Saharan Africa.

Environmental Engineering Science 26 (5), 1017-1023. DOI: 10.1089/ees.2008.0388.

Moriarty, P.; Smits, S.; Butterworth, J. and Franceys, R. 2013. Trends in rural water supply: Towards a service delivery approach. Water Alternatives 6 (3), 329-349.

Mosse, D., 2006. Collective Action, Common Property, and Social Capital in South India: An Anthropological Commentary. Economic Development and Cultural Change 54 (3), 695-724. DOI: 10.1086/500034.

Nabunnya, J., Mirembe, L., Magara, P., Watsisi, M., Otim, R., 2012. Community Management of Water Services. Approaches, Innovations from Lango \& Rwenzori regions, Uganda, IRC , Sustainable Services at Scale (Triple-S Uganda), Kampala, Uganda.

Narayan, D., 1995. The Contribution of People's Participation: Evidence from 121 Rural Water Supply Projects. Environmentally Sustainable Development Occasional Paper Series, No. 1. Washington, DC: World Bank.

North, D.C., 1990. Institutions, Institutional Change and Economic Performance. Cambridge University Press, Cambridge, UK.

Oates, N., Ross, R., Calow, R., Carter, R., Doczi, J., 2014. Adaptation to Climate Change in Water, Sanitation and Hygiene Assessing risks and appraising options in Africa. Water Policy Programme, Overseas Development Institute (ODI). <http://www.odi.org/sites/odi.org.uk/files/odi-assets/publications-opinionfiles/8858.pdf $>$ (accessed 02.02.2015). 
Ostrom, E., 1990. Governing the commons: the evolution of institutions for collective action. Cambridge University Press.

Ostrom, E., 1998. A behavioural approach to the rational choice theory of collective action. American Political Science Review, Vol. 92, No. 1: p. 1-22.

Ostrom, E., 2000. Collective action and the evolution of social norms. The journal of economic perspectives, Vol. 14, No. 3: p. 137-158.

Oxford/RFL., 2014. From Rights to Results in Rural Water Services - Evidence from Kyuso, Kenya. Smith School of Enterprise and the Environment, Water Programme, Working Paper 1, Oxford University, UK.

<http://www.smithschool.ox.ac.uk/research-programmes/water.php > (accessed 02.02.2015).

Page, B., 2003. Communities as the agents of commodification: the Kumbo Water Authority in Northwest Cameroon. Geoforum 34, 483-498.

Parry-Jones, S., Reed, R., Skinner, H., 2001. Sustainable Handpump Projects in Africa: A Literature Review. Water, Engineering and Development Centre, Loughborough University.

<http://wedc.lboro.ac.uk/docs/research/WEJW2/Literature_Review.pdf> (accessed 02.02.2015).

Putnam, R., 1993. The prosperous community: social capital and public life. American Prospects, 35-42.

Putnam,R., 2000. Bowling alone: the collapse and revival of American community. Simon and Schuster, NewYork.

Quin, A., Balfors, B., Kjellen., 2011. How to "walk the talk": The perspectives of sector staff on implementation of the rural water supply programme in Uganda. National Resources Forum 35 (4), 269-282. DOI: 10.1111/j.1477-8947.2011.01401.x

Rural Water Supply Network (RWSN)., 2010. Myths of the rural water supply sector. Perspectives Paper No. 4.

<file:///C:/Users/Lenovo/Downloads/Final\%20Myths\%203\%202010.pdf> (accessed 02.02.2015).

Sara, J., and Katz, T., 1998. Making Rural Water Supply Sustainable: Report on the Impact of Project Rules. Washington, DC: Water and Sanitation Program, World Bank. 
Schlosser, C.A., Strzepek, K., Gao, X., Fant, C., Blanc, E., Paltsev, S., Jacoby, H., Reilly, J., Gueneau, A., 2014. The future of global water stress: An integrated assessment. Joint Program Report Series. DOI: 10.1002/2014EF000238.

Schouten, T., Moriarty, P., 2003. Community Water, Community Management: From System to Service in Rural Areas. Practical Action Publishing, Rugby, UK.

Schouten, T., 2006. Scaling Up Community Management of Rural Water Supply. WELL factsheet. < http://www.lboro.ac.uk/well/resources/fact-sheets/fact-sheetshtm/Scaling\%20up.htm>

Scott, J.C., 1998. Address to the Seventh Annual Conference of the International Association for the Study of Common Property, Vancouver, 10-14 June.

Shiva, V., 2002. Water wars: privatization, pollution and profit. Cambridge, MA: South End Press.

Swyngedouw, E., 2006. Power, Water and Money: Exploring the Nexus. Human Development Report 2006. Human Development Report Office Occasional Paper. UNDP.

Thomson, P., Hope, R. Foster, T., 2012. GSM-enabled remote monitoring of rural handpumps: a proof-of-concept study. Journal of Hydroinformatics, 14 (4), 829-839.

Uganda Bureau of Statistics. 2014. National Population and Housing Census 2014, provisional results.

<http://unstats.un.org/unsd/demographic/sources/census/2010_PHC/Uganda/UGA2014-11.pdf $>$ (accessed 03.02.2015).

Van Koppen, B., Rojas, C.V., Skielboe, T., 2012. Project Politics, Priorities and Participation in Rural Water Schemes. Water Alternatives 5 (1): 1-15. <http://www.water-alternatives.org/index.php/volume5/v5issue1/156-a5-1-3/file> (accessed 02.02.2015).

Visscher, J.T., 1997. Technology transfer in the water supply and sanitation sector: a learning experience from Colombia. Technical paper Series 32-E, IRC/CINARA. <http://www.ircwash.org/sites/default/files/Visscher-1997-Technology.pdf>

Wasonga, V.O., Kambewa, D., Bekalo, I., 2010. Community-Based Natural Resource Management. In: Ochola, W., Sanginga, P. C., Bekalo, I. (Eds.) Managing Natural Resources for Development in Africa: A Resource Book. University of Nairobi Press, Nairobi, pp. 165-209.

Water and Sanitation Program., 2000. Linking sustainability with community participation and gender sensitivity. East and Southern Africa Region, Field Note 
Number 6. 〈http://www.ircwash.org/sites/default/files/WSP-2000-Linking.pdf $>$ (accessed 02.02.2015).

Webster, J., Dejachew, G., Bereket, G. T., Mehari, M., Tesfaye, G., 1999.

Sustainability of Rural Water and Sanitation Projects. Paper presented at the 25th WEDC Conference, Addis Ababa, Ethiopia.

<http://wedc.lboro.ac.uk/resources/conference/25/266.pdf $>$ (accessed 02.02.2015).

Whittington,D., Davis, J., Prokopy, L., Komives, K., Thorsten, R., Lukacsc, H., Bakalian, A,. Wakeman, A., 2009. How well is the demand-driven, community management model for rural water supply systems doing? Evidence from Bolivia, Peru and Ghana. Water Policy 11 (6), 696-718.

<http://web.stanford.edu/group/jennadavis/cgibin/drupal/sites/default/files/Whittingto nDavisWaterPolicy2009DemandDriven.pdf $>$ (accessed 02.02.2015).

DOI:10.2166/wp.2009.310.

Wong, C., Roy, M., Duraiappah, A.K., 2005. Connecting poverty and ecosystem services: A series of seven country scoping studies. United Nations Environment Programme and the International Institute for Sustainable Development.

< http://www.iisd.org/pdf/2005/economics_poverty_uganda.pdf > (accessed 14.01.2014).

Woolcock, M., Pritchett, L., 2004. Solutions when the solution is the problem: arraying the disarray in development. World Development 32 (2), 191-212.

DOI:10.1016/j.worlddev.2003.08.009

World Bank., 2010. A global review of private operator experiences in rural areas: private operator models for community water supply. WSP field note; Rural Water Supply series. Washington, DC: World Bank.

$<$ http://documents.worldbank.org/curated/en/2010/02/12752954/global-reviewprivate-operator-experiences-rural-areas-private-operator-models-community-watersupply> (accessed 02.02.2015)

World Health Organisation., 1992. The International Drinking Water and Supply Decade: End of decade review.

<http://whqlibdoc.who.int/hq/1992/WHO_CWS_92.12.pdf>

\section{Websites}

CIA World Fact Book. <https://www.cia.gov/library/publications/the-worldfactbook/rankorder/2002rank.html $>$ (accessed 14.01.2014). 
